\title{
Wsparcie przedsiębiorczości w procesie restrukturyzacii przemysłu okrętowego - przykład Bałtyckiego Portu Nowych Technologii
}

\section{Support for Entrepreneurship in Restructuring Shipbuilding Industry - the Example of Baltic Port of New Technologies}

\begin{abstract}
Streszczenie: Restrukturyzacja przedsiębiorstw jest naturalnym zjawiskiem w gospodarce kapitalistycznej. W transformującej się polskiej gospodarce był to jednak proces bardzo głęboki, skumulowany, turbulentny i społecznie kosztowny. Jedną z gałęzi przemysłu, w których trwał najdłużej i przyniósł bardzo zróżnicowane rezultaty, był przemysł okrętowy. Podstawowym celem artykułu jest przybliżenie procesu restrukturyzacji tego przemysłu na przykładzie Gdyni, ze szczególnym uwzględnieniem działań na rzecz wsparcia przedsiębiorczości, prowadzonych przez podmioty publiczne. W badaniach wykorzystano podejście indukcyjne. Przeprowadzono analizy opracowań naukowych, dokumentów planistycznych, sprawozdań z działalności, informacji na stronach internetowych instytucji. Jak wskazują wyniki badań, warunkiem sukcesu trudnego procesu restrukturyzacji, którego etapem była likwidacja dużej stoczni produkcyjnej, a następstwem rozwój grupy mniejszych, ale zróżnicowanych przedsiębiorstw, okazało się skoordynowane zaangażowanie kapitału prywatnego i publicznego. W proces ten włączyły się podmioty publiczne, modernizując infrastrukturę i tworząc m.in. Bałtycki Port Nowych Technologii. W ramach tego projektu oddano do użytku zaplecze naukowo-badawcze oraz biurowe dla dużych, małych i średnich przedsiębiorstw z branż gospodarki morskiej. Dzięki temu stworzono lepsze warunki do wdrażania nowych technologii w przemyśle okrętowym, jednocześnie dając impuls do wykorzystania innowacji w innych branżach. Wzmocniono zatem warunki do osiągnięcia korzyści aglomeracji typu porterowskiego. Uzyskane wyniki stanowią asumpt do dyskusji na temat czynników kształtujących odporność lokalnej gospodarki na kryzys, a także roli sektora publicznego w jej kształtowaniu.
\end{abstract}

\begin{abstract}
Restructuring of enterprises is a natural phenomenon in a capitalist economy. In a transforming Polish economy, it was a very deep, cumulated, turbulent and socially costly process. One of the industries in which it lasted for the longest and brought very varied results was the shipbuilding industry. The article aims primarily at presenting the restructuring process of this industry on the example of Gdynia, with particular emphasis on activities supporting public entities entrepreneurship. Inductive approach was used in the research. The authors have analysed case studies, planning documents, activity reports, an information contained on the websites of the institutions. The results indicate that the condition for the success of a difficult restructuring process, a stage of which was the closing down of a large shipyard and then the development of the smaller but varied businesses was a joint involvement of private and public capital. Public entities took part in the process by improving infrastructure and creating, among others, the Baltic Port of New Technologies. Within the project, research facilities and offices for maritime industry based companies of all sizes were supplied. Thanks to it better conditions for the implementation of new technologies in the shipbuilding industry were created, at the same time other sectors were provided with a stimulus to use innovations. Therefore, Porter agglomeration economies have been strengthened. The results are the starting
\end{abstract}


point for discussion on factors affecting the resilience of the local economy against crisis and the role of the public sector in improving this feature.

Słowa kluczowe: Gdynia; interwencja publiczna; przedsiębiorczość; przemysł okrętowy; restrukturyzacja przemysłu

Keywords: entrepreneurship; Gdynia; industrial restructuring; public intervention; shipbuilding industry

Otrzymano: 22 grudnia 2015

Received: 22 December 2015

Zaakceptowano: 13 lipca 2016

Accepted: 13 July 2016

Sugerowana cytacja / Suggested citation:

Palmowski, T., Tarkowski, M. (2016). Wsparcie przedsiębiorczości w procesie restrukturyzacji przemysłu okrętowego - przykład Bałtyckiego Portu Nowych Technologii. Prace Komisji Geografii Przemysłu Polskiego Towarzystwa Geograficznego, 30(3), 159-172.

\section{WSTĘP}

Punktem wyjścia do analizy poruszanej w artykule problematyki jest koncepcja kreatywnej destrukcji, zgodnie z którą permanentne powstawanie i upadek przedsiębiorstw są zjawiskami koniecznymi do rozwoju gospodarki kapitalistycznej (Schumpeter, 1960). W ujęciu mikroekonomicznym cykl życia przedsiębiorstwa może być przedłużany przez restrukturyzację podmiotową (przekształcenia prawno-ekonomiczne), przedmiotową (zmiany techniki, technologii i oferowanego asortymentu), naprawczą (poprawa niekorzystnych wyników ekonomicznych) lub rozwojową (innowacje) (Stabryła, 2011). W skali mezo- i makroekonomicznej restrukturyzacja może następować nie tylko na skutek przekształceń samych firm, ale właśnie w wyniku działania mechanizmu kreatywnej destrukcji, czyli poprzez wyeliminowanie z gospodarki podmiotów tracących pozycję konkurencyjną i stworzenie w ten sposób warunków dla rozwoju przedsiębiorstw ją zyskujących (Mitchell, Mulherin, 1996). Wydaje się, że w warunkach silnej globalnej konkurencji, która cechuje współczesną gospodarkę (Porter, 2001), zjawisko kreatywnej destrukcji odgrywa coraz większą rolę w jej rozwoju (Florida, 1996; Acs, Preston, 1997), a procesy restrukturyzacji nabierają permanentnego charakteru (Borowiecki, 2010).

Model transformacji ustrojowej przyjęty w Polsce, stawiający na szybkie przejście od gospodarki planowej do rynkowej, spowodował, że przedsiębiorstwa państwowe, dominujące niemal w każdym aspekcie produkcji przemysłowej, miały bardzo mało czasu na restrukturyzację, która musiała się toczyć nie tylko w warunkach rosnącej konkurencji międzynarodowej, ale także w nieprzyjaznym własności państwowej otoczeniu instytucjonalnym (Karpiński, Paradysz, Soroka, Żółtkowski, 2013). Wyniki badań losów zakładów przemysłowych funkcjonujących w 1998 roku, przeprowadzone po 25 latach transformacji, wskazują, że niekwestionowane sukcesy (unowocześnienie technologii i organizacji produkcji, podniesienie wydajności pracy, obniżenie materiało- i energochłonności produkcji, a co za tym idzie, zanieczyszczenia środowiska, oraz odtworzenie powiązań z rynkiem światowym) były bardzo kosztowne - zlikwidowano 
43\% istniejących zakładów, straty majątku wyniosły 37\%, produkcji - 38\%, a zatrudnienia prawie 50\% całego potencjału badanych podmiotów (Paradysz, 2015). Analizy odnoszące się do całości przemysłu w okresie transformacji ustrojowej potwierdzają zaistniałą niejednoznaczność - wskazują na istotne sukcesy, ale i porażki przekształceń tej dziedziny gospodarki (Rachwał, 2011). Doświadczenia te wskazują, że restrukturyzacja prowadzona w niesprzyjających warunkach często skutkuje destrukcją pojedynczych przedsiębiorstw, a czasami całych branż, w miejsce których nie tworzy się nowy potencjał w skali równoważącej straty.

Przemysł okrętowy obejmuje budowę i remonty statków. Produkcja ma charakter jednostkowy - w przypadku każdego statku (nawet budowanego seryjnie) zależy od konkretnych potrzeb armatora. Cechują ją wysoka materiałochłonność oraz długi i złożony proces produkcyjny (A. Antonowicz, P. Antonowicz, Bieliński, Płoska, Valtanen, 2007). Jakość produkcji statku warunkują przepisy międzynarodowe. Polskie stocznie działające w ramach gospodarki planowej, budując w większości jednostki dla państw Rady Wzajemnej Pomocy Gospodarczej, miały dzięki tym wymogom większy kontakt ze światową gospodarką niż inne przedsiębiorstwa przemysłowe. Aby sprostać tym wymaganiom, musiały być też względnie nowocześnie wyposażone. Z jednej strony były więc stosunkowo dobrze przygotowane do konkurencji na rynkach międzynarodowych, z drugiej zaś w okresie transformacji ustrojowej musiały zmierzyć się z rosnącą, globalną presją konkurencyjną. Najpoważniejszymi ich rywalami okazały się stocznie dalekowschodnie - głównie japońskie, koreańskie i chińskie - które dzięki silnemu wsparciu ze strony państwa stały się ważnymi motorami rozwoju gospodarczego tych krajów i zdobyły znaczą część rynku, zdominowaną przed kryzysem naftowym lat siedemdziesiątych XX wieku przez stocznie europejskie.

Słabość polskiego przemysłu okrętowego okresu transformacji ustrojowej polegała na niezdolności do: produkcji innych statków niż masowo wytwarzane w stoczniach wymienionych państw, znalezienia innych odbiorców niż kupujący w stoczniach dalekowschodnich oraz funkcjonowania w gronach przemysłowych. Dodać do tego należy małą efektywność, słabość otoczenia instytucjonalnego i niskie kwalifikacje pracowników. W rezultacie obok stoczni o bogatych tradycjach, choć stopniowo tracących swoją pozycję konkurencyjną, powstawać zaczęły zakłady wyspecjalizowane w produkcji prefabrykatów - sekcji i całych kadłubów - czyli ulokowane bardzo nisko w łańcuchu wartości i konkurujące względnie niskimi kosztami pracy (Błuś, 2016). Stanowiło to wyraźny symptom degradacji tej gałęzi przemysłu. Proces upadku dużych stoczni produkcyjnych zakończył się w 2009 roku likwidacją zakładów w Gdyni i Szczecinie.

Podstawowym celem artykułu jest przybliżenie przebiegu ostatniego etapu procesu restrukturyzacji przemysłu okrętowego, jaki nastąpił po 2009 roku. Wybrano Gdynię, w której - w przeciwieństwie do Szczecina - restrukturyzację poprzez likwidację, sprzedaż majątku, modernizację infrastruktury i wsparcie przedsiębiorczości ${ }^{1}$ udało się, jak do tej pory (2015 rok), prowadzić z powodzeniem. Zgodnie z główną hipotezą tej pracy zakończony powodzeniem proces restrukturyzacji był następstwem unikania błędów typowych dla okresu transformacji ustrojowej, które wynikały z wycofania się

${ }^{1} \mathrm{~W}$ niniejszym artykule przedsiębiorczość analizowana jest głównie jako funkcja indywidualnego przedsiębiorstwa i rynku (Wach, 2015). 
instytucji państwowych z aktywnego i jednocześnie prorozwojowego wspierania przedsiębiorstw. W analizowanym przypadku terenów po upadłej stoczni zasadniczo nie przeznaczono do innych celów, udało się znaleźć nabywców zdolnych do produkcji statków i produktów na potrzeby przemysłu morskiego. Zmodernizowano również infrastrukturę techniczną oraz oddano do użytku zaplecze naukowo-badawcze oraz biurowe dla dużych, małych i średnich przedsiębiorstw z branż gospodarki morskiej. Dzięki temu stworzono lepsze warunki do wdrażania nowych technologii w przemyśle okrętowym, jednocześnie dając impuls do wykorzystania innowacji w innych branżach. Wzmocnione zostały więc warunki do osiągnięcia korzyści aglomeracji typu porterowskiego.

Wydaje się zatem, że omawiany przypadek spełnia kryteria kreatywnej destrukcji. Co szczególnie ważne, podmiotami aktywnymi w omawianych przekształceniach były nie tylko prywatne przedsiębiorstwa, ale także podmioty kontrolowane przez państwo i instytucje samorządowe, co potwierdza tezę o szczególnych związkach między przemysłem okrętowym a polityką, wynikających z jego roli strategicznej, gospodarczej i społecznej (Bruce, Garrard, 2013). W celu weryfikacji postawionej hipotezy przeanalizowano publikacje naukowe, raporty i czasopisma branżowe, dokumenty planistyczne, sprawozdania z działalności oraz informacje na stronach internetowych instytucji. Artykuł rozpoczyna omówienie najważniejszych etapów rozwoju i restrukturyzacji Stoczni Gdynia SA. Następnie przedstawiono krótką charakterystykę podmiotów, które nabyły tereny po zlikwidowanej stoczni i tym samym rozpoczęły ostatni etap restrukturyzacji. Dwie kolejne części poświęcono omówieniu celów i przebiegu interwencji publicznej - w zakresie modernizacji infrastruktury technicznej, a także badawczo-rozwojowej i biurowej. Pracę zamykają wnioski wraz z dyskusją wyników w kontekście debaty na temat czynników kształtujących odporność lokalnej gospodarki na kryzysy oraz roli sektora publicznego w jej kształtowaniu.

\section{ROZWÓJ, REGRES I UPADEK STOCZNI GDYNIA SA}

Geneza gdyńskiego, a tym samym polskiego przemysłu okrętowego sięga 1922 roku, kiedy to w budowanym porcie powstała Stocznia Gdynia. Jednak do wybuchu II wojny światowej prowadziła ona działalność na bardzo ograniczoną skalę. Dopiero przedsiębiorstwo państwowe powstałe w 1951 roku - Stocznia im. Komuny Paryskiej - stało się masowym producentem statków. Do końca funkcjonowania zakładu w roku 2009 zbudowano ich łącznie 620. W latach sześćdziesiątych XX wieku w stoczni budowano drobnicowce i masowce o nośności od 10 do 26 tys. t. W latach siedemdziesiątych nośność budowanych masowców osiągnęła tu najpierw 50 tys. t, a potem 105 tys. t. W stoczni budowano także różnego rodzaju trawlery i inne statki rybackie. Szczególne wyzwanie technologiczne i techniczne stanowiła budowa statków do przewozu samochodów, przystosowanych do jednorazowego załadunku 6 tys. pojazdów osobowych, specjalistycznych jednostek do przewozu skroplonego gazu, promów pasażersko-samochodowych. Budowano także kontenerowce o pojemności do 4,5 tys. TEU, chłodnicowce, statki pasażerskie, zbiornikowce, jednostki ro-ro, statki szkolne oraz doki pływające. Odbiorcami zbudowanych w stoczni jednostek byli armatorzy z 25 krajów świata. 
W tym czasie stocznia była rozbudowywana i modernizowana. W rezultacie tych zmian zakład przekształcony w Stocznię Gdynia SA zajmował w 1991 roku teren o powierzchni 134 ha. W skład jego wyposażenia wchodziły m.in. dwa suche doki. Pierwszy był długi na $241 \mathrm{~m}$ i głęboki na $8 \mathrm{~m}$. Obsługiwany był przez suwnicę o udźwigu $500 \mathrm{t}$ i dwa żurawie o udźwigu 80 t. Drugi suchy dok miał 380 m długości, 70 m szerokości i 8 m głębokości. Towarzyszyła mu suwnica o największym w Polsce udźwigu - 900 t, zastąpiona później kolejną o udźwigu 1000 t. Dok obsługiwały również trzy dźwigi o udźwigu 150 t i dwa - 20 t (Stocznia Gdynia SA, 2016). Stocznia należała do najlepiej wyposażonych zakładów w Europie, jednak utraciła już prymat w przemyśle okrętowym na rzecz krajów dalekowschodnich. Mimo silnej konkurencji okresowo notowała bardzo dobre rezultaty.

W 2003 roku stocznia zajmowała pierwsze w Europie i piętnaste w świecie miejsce w kategorii wielkości produkcji. Zaczęła jednak notować coraz gorsze wyniki finansowe w następstwie sukcesywnej utraty przewag konkurencyjnych. Proces restrukturyzacji, a także próba poszukiwania inwestora, nie przyniosły oczekiwanego rezultatu. W listopadzie 2008 roku Komisja Europejska uznała, że udzielona przez polski rząd pomoc publiczna, m.in. zakładowi w Gdyni, jest nielegalna. Zgodnie z planem uzgodnionym z Komisją podzielony na części majątek stoczni został wystawiony na sprzedaż, a pracowników zwolniono. Od marca 2009 roku, na podstawie uchwalonej w zaistniałych okolicznościach ustawy o postępowaniu kompensacyjnym, rozpoczęto likwidację Stoczni Gdynia pod względem prawnym, wyprzedaż jej majątku oraz zwolnienia grupowe pracowników. Ostatnie wodowanie miało miejsce 25 kwietnia 2009 roku. Zwolnienia zakończono miesiąc później.

W kontekście interwencji państwa w obszarze gospodarki i wspierania przedsiębiorczości należy podkreślić fakt, że likwidacji stoczni towarzyszył specjalny program, umożliwiający byłym pracownikom przekwalifikowanie. Jednocześnie majątek stoczni został podzielony w taki sposób, aby był atrakcyjny dla potencjalnych nabywców i umożliwiał jego wykorzystanie pod względem technicznym i technologicznym. Stworzyło to szansę na zachowanie dotychczasowego charakteru produkcji. Biorąc pod uwagę liczne powiązania kooperacyjne, konieczne do budowy statków, zachowano szansę na odtworzenie powiązań z licznymi podmiotami działającymi w otoczeniu stoczni (P. Antonowicz, A. Antonowicz, 2009) i przywrócenie zaopatrzeniowych efektów mnożnikowych dla lokalnej gospodarki.

\section{ROZWÓJ PRZEDSIĘBIORSTW NA TERENIE ZLIKWIDOWANEJ STOCZNI GDYNIA SA}

W toku postępowania kompensacyjnego majątek po stoczni nabyły prywatne podmioty - producenci statków i ich podzespołów. Największą rolę zaczęły odgrywać dwie stocznie - Crist i Stocznia Remontowa Nauta. Crist wyspecjalizował się w budowie nowoczesnych statków rybackich i statków specjalistycznych, przeznaczonych głównie do obsługi platform wydobywczych, budowy i obsługi morskich farm wiatrowych oraz prowadzenia badań na morzu. Stocznia Remontowa Nauta umocniła swoją pozycję konkurencyjną na rynku remontu statków, prowadząc kompleksowe remonty 
i przebudowy. Uruchomiony w Gdańsku Zakład Nowych Budów umożliwił również ekspansję w segmencie budowy jednostek. Podobnie jak Crist wykonuje zamówienia na statki rybackie i specjalistyczne. Uzupełnieniem przemysłu okrętowego są przedsiębiorstwa, które z jednej strony współpracują ze stoczniami, z drugiej zaś oferują rozwiązania na potrzeby przemysłu morskiego (ryc. 1, tab. 1).

Ryc. 1. Główne firmy prowadzące działalność na terenach po Stoczni Gdynia SA

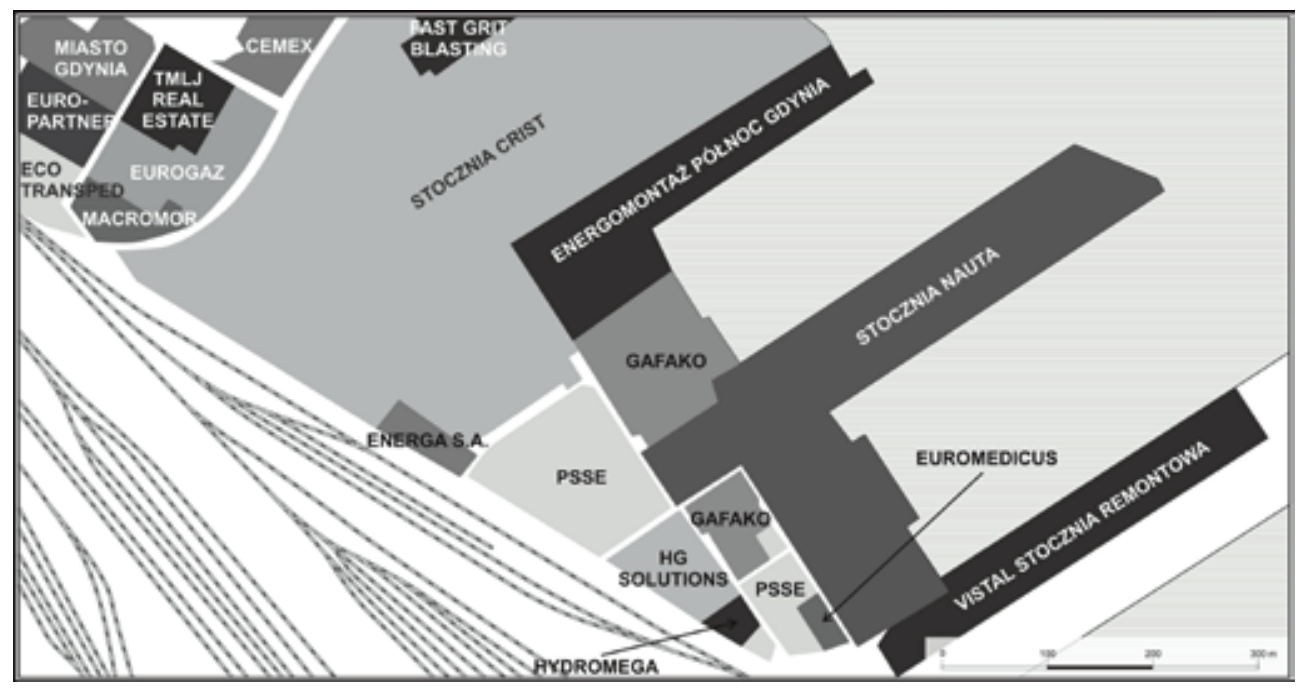

Źródło: opracowanie własne na podstawie: Bałtycki Port Nowych Technologii (2016a)

Główną cechą omawianego etapu restrukturyzacji przemysłu okrętowego w Gdyni było wprowadzenie w miejsce jednego dużego zakładu² większej liczby mniejszych i niezależnych przedsiębiorstw, zarządzanych w bardziej efektywny i elastyczny sposób. Taka struktura umożliwiła znalezienie nowych rynków zbytu, w których korzyści skali oferowane przez największych dalekowschodnich producentów nie są tak istotne, a także znaczną dywersyfikację asortymentu produktów. Jedną z ważniejszych ról w tym procesie odegrała stocznia Crist. Jej twórcami byli inżynierowie budowy okrętów, a więc osoby wywodzące się z branży, mające jednak własną wizję zarządzania przedsiębiorstwem. Z uwagi na kapitałową barierę wejścia charakterystyczną dla tego przemysłu, spółka zaczynała działalność jako podwykonawca. Seria trudnych, ale zakończonych sukcesem kontraktów umocniła jej pozycję konkurencyjną. Umożliwiło to ubieganie się o pożyczkę na zakupy inwestycyjne udzieloną w 2010 roku przez Agencję Rozwoju Przemysłu, dzięki której sfinansowany został zakup terenów po zlikwidowanej stoczni (rejon prefabrykacji kadłubów i rejon montażu statków) umożliwiający budowę dużych jednostek pływających. Ważnym czynnikiem sukcesu restrukturyzacji

${ }^{2} \mathrm{~W}$ ostatnim okresie funkcjonowania przedsiębiorstwa działalność prowadziło równolegle dziewięć spółek zależnych, których podstawowym przedmiotem działalności było świadczenie usług na rzecz stoczni. Ich potencjał w stosunku do spółki-matki był niewielki. Z tych powodów traktowane są one jako funkcjonalne składowe jednego zakładu. 
okazała się więc spółka, początkowo była zaliczana do grupy przedsiębiorstw nisko umocowanych w łańcuchu wartości dodanej, której powstawanie było następstwem słabnącej pozycji konkurencyjnej polskiego przemysłu okrętowego. Determinacja jej twórców w dążeniu do rozwoju oraz zdolność do umocnienia pozycji w segmentach rynku w mniejszym stopniu narażonych na konkurencję cenową wydają się być jednym z kluczowych elementów sukcesu całego procesu przekształceń.

Drugi z największych podmiotów - Stocznia Remontowa Nauta - swoją pozycję konkurencyjną zawdzięcza z jednej strony wykonywaniu coraz bardziej skomplikowanych przebudów i remontów statków, z drugiej - poszerzeniu zakresu działalności o produkcję nowych statków. Stocznia ta jest ciekawym przykładem adaptacji przemysłu poprzez relokację (Stryjakiewicz, 1999). Z uwagi na charakter produkcji wybór miejsca jest bardzo ograniczony. Likwidacja Stoczni Gdynia SA dała Naucie szansę zyskania terenów pozwalających na większy rozwój. Dotychczasowa lokalizacja w bezpośrednim sąsiedztwie śródmieścia stanowiła pod tym względem ograniczenie. Relokacja pozwoliła też miastu inaczej zagospodarować zwolniony obszar. Biorąc pod uwagę jego atrakcyjne położenie, należy się spodziewać znacznego zainteresowania przedsiębiorców. Pośrednio jest to także rodzaj wsparcia przedsiębiorczości.

Tab. 1. Charakterystyka działalności wybranych podmiotów (poza głównymi stoczniami) zlokalizowanych na terenach po Stoczni Gdynia SA

\begin{tabular}{|l|l|}
\hline \multicolumn{1}{|c|}{ Nazwa podmiotu } & \multicolumn{1}{|c|}{ Charakterystyka działalności } \\
\hline Vistal Stocznia Remontowa Sp. & $\begin{array}{l}\text { remonty statków, produkcja i obróbka wielkogabarytowych } \\
\text { konstrukcji stalowych, wykonywanie powłok antykorozyjnych }\end{array}$ \\
\hline $\begin{array}{l}\text { Energomontaż-Północ Gdynia } \\
\text { Sp. z o.o. }\end{array}$ & $\begin{array}{l}\text { budowa modułów i sekcji platform wiertniczych, wież obsługowych, } \\
\text { konstrukcji stalowych dla elektrowni wiatrowych, unikatowych } \\
\text { konstrukcji morskich; budowa rurociągów, konstrukcji stalowych dla } \\
\text { przemysłu budowy i remontów statków; remonty i budowa statków }\end{array}$ \\
\hline Gafako Sp. z o.o. & $\begin{array}{l}\text { wytwarzanie i obróbka mechaniczna konstrukcji stalowych, } \\
\text { wyżarzanie odprężające konstrukcji stalowych, zwijanie blach, usługi } \\
\text { w zakresie cięcia gazowego i plazmowego blach, montaż mechaniczny } \\
\text { i hydrauliczny urządzeń }\end{array}$ \\
\hline Hydromega Sp. z o.o. & $\begin{array}{l}\text { projektowanie i produkcja układów hydrauliki siłowej, automatyka } \\
\text { przemysłowa, produkcja zasilaczy hydraulicznych oraz urządzeń } \\
\text { z napędem hydraulicznym }\end{array}$ \\
\hline HG Solutions Sp. z o.o. & $\begin{array}{l}\text { produkcja rozdzielnic elektrycznych oraz osprzętu elektrycznego dla } \\
\text { przemysłu morskiego }\end{array}$ \\
\hline Makromor Sp. z o.o. & $\begin{array}{l}\text { produkcja protektorów do antykorozyjnej ochrony katodowej } \\
\text { kadłubów }\end{array}$ \\
\hline
\end{tabular}

Źródło: opracowanie własne na podstawie: Bałtycki Port Nowych Technologii (2016b)

Przy omawianiu roli najważniejszych firm w procesie restrukturyzacji przemysłu okrętowego w Gdyni należy także wskazać na zaangażowanie instytucji sektora publicznego. Stocznia Remontowa Nauta SA oraz Energomontaż-Północ Gdynia funkcjonują w ramach grupy Mars Shipyards \& Offshore, będącej częścią Funduszu Inwestycyjnego Zamkniętego Mars, powołanego przez Agencję Rozwoju Przemysłu. W 2013 roku fundusz ten stał się też akcjonariuszem stoczni Crist. Po części było to następstwem 
trudności finansowych, w jakie popadła spółka w toku budowy innowacyjnych statków na potrzeby przemysłu morskiego. Duże zaangażowanie sektora publicznego w znalezienie nabywców majątku upadłej stoczni, którzy będą zdolni do kontynuacji produkcji, wynikało z trudnej sytuacji makroekonomicznej. Proces kompensacji przebiegał w okresie transmisji skutków światowego kryzysu finansowego do gospodarek poszczególnych krajów.

Przemysł okrętowy jest bardzo wrażliwy na wahania koniunkturalne, które bezpośrednio kształtują potrzeby transportowe. Gdy weźmiemy pod uwagę tę okoliczność, to wydaje się, że aktywność podmiotów zależnych od państwa była kolejnym ważnym czynnikiem powodzenia opisywanych przekształceń. Udział instytucji spoza sektora przedsiębiorstw na tym się jednak nie kończył. Pozostałe tereny po zlikwidowanej stoczni nabyła Pomorska Specjalna Strefa Ekonomiczna (PSSE). Dokonano istotnych inwestycji w modernizację infrastruktury technicznej, zaplecza badawczo-rozwojowego oraz biurowego, a na większości terenów zlikwidowanego zakładu utworzono podstrefę tejże specjalnej strefy ekonomicznej. Poszerzyło to zakres możliwych do stosowania narzędzi pomocy publicznej. Całemu projektowi modernizacji infrastruktury i rozwoju usług dla biznesu PSSE nadała nazwę Bałtycki Port Nowych Technologii.

\section{INTERWENCJA PUBLICZNA - MODERNIZACJA INFRASTRUKTURY TECHNICZNEJ}

Następstwem podziału terenu zlikwidowanej Stoczni Gdynia SA było wydzielenie nieruchomości o charakterze przestrzeni publicznych - głównie dróg i ciągów pozostałej infrastruktury technicznej. Nabywców nie znalazły również dwa duże, ale zdegradowane budynki biurowe. W celu modernizacji tej infrastruktury w końcu 2012 roku lokalny samorząd uchwalił nowy miejscowy plan zagospodarowania przestrzennego. Przyjęte ustalenia pozwoliły na zachowanie przemysłowego charakteru obszaru, w szczególności wskazano na działalność stoczniową i okołostoczniową. Zaproponowane rozwiązania drogowe pozwoliły usprawnić transport w tym rejonie. Sieć dróg publicznych umożliwiła niezależny dostęp do każdego przedsiębiorstwa. Przewidziano także możliwość modernizacji dróg zbiorczych w sąsiedztwie opisywanego terenu. W dokumencie określono również gęstość i wysokość zabudowy - wartość drugiego parametru to $55 \mathrm{~m}$.

Dzięki inicjatywie i działaniom PSSE w latach 2012-2013 na zdegradowanych terenach postoczniowych zapoczątkowano proces porządkowania i rewitalizacji. Wyburzono stare budynki, kolidujące z planowanymi inwestycjami infrastrukturalnymi. Rozpoczęto budowę sieci wodno-kanalizacyjnej i deszczowej oraz nowej sieci ciepłowniczej. W następnym roku bezpieczeństwo energetyczne zapewnił nowoczesny główny punkt zasilania. W miejscu dawnej bramy wjazdowej do stoczni powstało rondo i drogi prowadzące do podmiotów zlokalizowanych na terenie Bałtyckiego Portu Nowych Technologii. We współpracy z trójmiejskimi uczelniami opracowano koncepcję programu użytkowego dla historycznego budynku dawnej elektrociepłowni oraz projekt zagospodarowania estetyczno-funkcjonalnego obejmującego tereny zieleni, małą architekturę, parkingi i budynki biurowe. 


\section{INTERWENCJA PUBLICZNA - ZAPLECZE BADAWCZO-ROZWOJOWE I BIUROWE}

Pomorska Specjalna Strefa Ekonomiczna podjęła się również modernizacji dwóch budynków biurowych pozostałych po zlikwidowanej stoczni, na które nie znaleziono nabywców. Na początku 2013 roku otwarto ponownie mający 5,6 tys. $\mathrm{m}^{2}$ powierzchni biurowej budynek dawnej siedziby dyrekcji stoczni (w nomenklaturze stoczni oznaczony symbolem G-330). Oferowane są biura w standardzie B+, zaplecze gastronomiczne, konferencyjne oraz unikatowa lokalizacja w sąsiedztwie przedsiębiorstw będących liderami gospodarki morskiej, ponadto atrakcyjna panorama miasta i portu (Bałtycki Port Nowych Technologii, 2016c). Ich użytkownikami zostały firmy działające przede wszystkim w obszarze gospodarki morskiej - głównie z branży stoczniowej oraz transportu, spedycji i logistyki. W połowie 2016 roku w budynku miało biura blisko 100 podmiotów.

W kolejnym, ośmiopiętrowym budynku o powierzchni 5,6 tys. $\mathrm{m}^{2}$ (w nomenklaturze stoczni oznaczonym symbolem G-321) wydzielone zostały kondygnacje z przeznaczeniem na prototypownie, wzorcownie, warsztaty i pracownie projektowe, przystosowane do tzw. czystej produkcji: elektroniki, automatyki, robotyki i inżynierii, pracownie wzornictwa przemysłowego dla architektów i artystów oraz pomieszczenia biurowe. Przedsięwzięcie to zyskało własną nazwę - Park Konstruktorów. Został on otwarty pod koniec 2015 roku. Jego specyfiką jest oferta skierowana do przedsiębiorstw budujących statki i konstrukcje morskie. Składają się na nią m.in.: Pracownia Badań Nieniszczących i Niszczących, Pracownia Łączności i Nawigacji oraz Wzorcownia Przyrządów Pomiarowych (Pomorski Park Naukowo-Technologiczny, 2016b). Projekt ten rozwijany jest we współpracy z Pomorskim Parkiem Naukowo-Technologicznym Gdynia (PPNT) i stanowi odpowiedź na duże zapotrzebowanie na tego typu specjalistyczną infrastrukturę, które zaobserwowano wcześniej w PPNT. Nabór podmiotów chcących prowadzić działalność w Parku Konstruktorów prowadzony jest w formule konkursowej, na podstawie oceny trzech kryteriów: innowacyjności danego podmiotu i projektu, jaki zamierza realizować; wpływu na wzrost zatrudnienia; realności i trwałości planowanego projektu. Aplikacje oceniają eksperci PPNT i PSSE, a umowa podpisywana jest na trzy lata (Pomorski Park Naukowo-Technologiczny, 2016a). W połowie 2016 roku wyniki konkursu nie były jeszcze znane.

\section{WNIOSKI}

Przeprowadzona analiza pozwoliła na weryfikację głównej hipotezy, zakładającej, że zakończony powodzeniem proces restrukturyzacji był następstwem unikania błędów typowych dla okresu transformacji ustrojowej, które wynikały z wycofania się instytucji państwowych z aktywnego i jednocześnie prorozwojowego wspierania przedsiębiorstw. W toku analizy wskazano na krytyczne dla analizowanego przypadku czynniki, które spowodowały, że trudny proces restrukturyzacji nabrał cech typowych dla zjawiska kreatywnej destrukcji. 
Po pierwsze, w celu złagodzenia skutków upadku dużych stoczni produkcyjnych w Gdyni i Szczecinie przyjęto specjalne regulacje prawne, które pozwoliły na przeprowadzenie masowego programu przekwalifikowania zwalnianych pracowników. Określono także zasady podziału i sprzedaży majątku w taki sposób, aby umożliwić jego dalsze wykorzystanie pod względem technicznym i technologicznym. Choć do przebiegu programu zgłoszono zastrzeżenia (Najwyższa Izba Kontroli, 2011), to w trudnym dla przemysłu okrętowego okresie dekoniunktury udało się znaleźć nabywców zdolnych do prowadzenia produkcji o zbliżonym profilu. Było to jednak możliwe dzięki aktywnemu zaangażowaniu Agencji Rozwoju Przemysłu - spółki Skarbu Państwa.

Po drugie, krytyczne znaczenie dla całego procesu miała zdolność nowych właścicieli majątku do jego efektywnego wykorzystania. Potrafili on diametralnie zmienić profil produkcji okrętowej, skupiając się na specjalistycznych segmentach rynku budowy i remontów, w mniejszym stopniu narażonych na konkurencję cenową ${ }^{3}$ Stocznia Gdynia SA nie była w stanie dokonać tego rodzaju zmiany przez cały okres transformacji ustrojowej, co było podstawową przyczyną jej upadku. W tym sensie sukces przekształceń zależał od przedsiębiorczości jako funkcji czynności menedżerskich, działania pojedynczych przedsiębiorstw, jak i całej ich grupy w ramach łańcucha wartości, którego finalnym wytworem jest statek lub konstrukcja morska. To, że w Szczecinie proces restrukturyzacji się nie udał, wynikało najprawdopodobniej z deficytów w omawianym zakresie.

Po trzecie, warunkiem koniecznym powodzenia były skoordynowane działania władz centralnych i samorządu lokalnego. Pomorska Specjalna Strefa Ekonomiczna, której głównym właścicielem jest Skarb Państwa, podjęła się procesu modernizacji infrastruktury technicznej, badawczo-rozwojowej i biurowej we współpracy z władzami Gdyni, które uchwaliły odpowiedni miejscowy plan zagospodarowania przestrzennego, a poprzez Pomorski Park Naukowo-Technologiczny, będący jednostką budżetową miasta, przystąpiły także do prac nad rozwojem Parku Konstruktorów.

W rezultacie opisanych procesów udało się zachować najważniejsze składniki majątku upadłej stoczni, odtworzyć - na co wskazują szacunkowe dane - liczbę miejsc pracy i znaleźć rynki, na których udało zająć się stosunkowo silną pozycję konkurencyjną. Zaobserwowane przemiany wpisują się we wzorzec transformacji struktur przemysłowych, polegający na odejściu od modelu opartego przede wszystkim na korzyściach skali do modelu elastycznej produkcji, w większym stopniu wykorzystującego współpracę dużej liczby mniejszych podmiotów i wynikające z tego korzyści aglomeracji (Scott, 1988; Storper, 1989; Duguay, Landry, Pasin, 1997). Choć na obecnym etapie rozwoju nie można wyciągać daleko idących wniosków, to wydaje się, że działalność Bałtyckiego Portu Nowych Technologii i zlokalizowanych w nim podmiotów sprzyja wzmacnianiu podstaw typowych dla gron przemysłowych przewag konkurencyjnych w zakresie wydajności oraz innowacyjności (Porter, 2001). BPNT samodzielnie nie stanowi grona, jest jednak częścią większej tego typu struktury istniejącej na Pomorzu (Brodzicki, Zaucha, 2013) i być może usprawni jego funkcjonowanie.

${ }^{3}$ Skalę tej zmiany obrazuje porównanie wartości 1 kg masy statku. Na początku lat dziewięćdziesiątych wartość 1 kg kontenerowca produkowanego w polskich stoczniach wahała się w granicy 3 dol. W 2015 roku wartość ta wzrosła do kilkunastu, a w skrajnych przypadkach nawet do 20 dol. (Czuczman, 2015). 
Dla przemysłu okrętowego charakterystyczne są cykliczne fluktuacje popytu i brak elastyczności możliwości produkcyjnych i usługowych (A. Antonowicz, P. Antonowicz, Bieliński, 2007). Obecność w bezpośrednim (BPNT) i dalszym otoczeniu podmiotów, do których można delegować część pracy (outsourcing i kooperacja) (P. Antonowicz, A. Antonowicz, 2009) pozwala na ograniczenie kosztów, bardziej elastyczne reagowanie na zmiany popytu i skupienie się na doskonaleniu podstawowej działalności. To kolejny atut zróżnicowanej struktury podmiotów, która wykształciła się w następstwie likwidacji Stoczni Gdynia SA. Pociąga ona jednak za sobą niebezpieczeństwo obniżenia warunków pracy u podwykonawców.

Wyższa specjalizacja i elastyczność uzyskana w toku restrukturyzacji sprzyja podniesieniu odporności na kryzys. Jak pokazują analizy, województwo pomorskie cechuje się stosunkowo niskim jej poziomem. Od 2009 roku, w którym to upadła stocznia, odnotowano względne spowolnienie rozwoju (Churski, 2011). Województwo notuje wysoką koncentrację towarową eksportu. Statki, łodzie i konstrukcje pływające stanowiły w latach 2008-2014 od 28 do 35\% eksportu (Umiński, Wojnicka-Sycz, Brodzicki, Gawlikowska-Hueckel, Kwiatkowski, 2015). Gospodarka regionu jest więc dość podatna na wahania koniunktury z powodu dużej wrażliwości głównego produktu eksportowego. Obecny profil produkcji, w którym nie występują typowe statki towarowe, nie jest podatny na zmiany popytu na usługi transportowe drogą morską. Jest jednak silnie zależny od zamówień na specjalistyczne statki do obsługi pól naftowych. Bardzo niskie ceny ropy przyczyniają się do spadku tego typu zamówień. Zaczął on być odczuwalny także w polskich stoczniach. Reakcja nowo powstałej struktury będzie pierwszym poważnym testem jej odporności, a zarazem zagadnieniem do dalszych badań w perspektywie najbliższych lat.

Dotychczasowe analizy terytorialnej odporności na kryzys wskazują na znaczenie takich czynników, jak: struktura gospodarki (Martin, 2012), stopień jej umiędzynarodowienia, endogenicznie generowana wiedza, zdolności menedżerskie (Simmie, Martin, 2010). Zagadnienia te mają znaczenie także w analizowanym przypadku. Ponadto waga odporności na kryzys jest na tyle duża, że poszukiwane są sposoby jej wzmocnienia $\mathrm{w}$ formie recept dla polityki regionalnej i lokalnej. Przegląd dotychczasowych badań w tym zakresie (Christopherson, Michie, Tyler, 2010) wskazuje na odmienność terytorialnych uwarunkowań odporności na kryzys, a tym samym na potencjalnie bardzo różnorodny zestaw recept. Z tej perspektywy działania podejmowane w Gdyni w latach 2009-2015 trudno interpretować w kategorii jakiegokolwiek wzorca. Wydaje się jednak, że przynajmniej w odniesieniu do kapitałochłonnego przemysłu budowanie tej odporności wykracza poza możliwości przedsiębiorstw i wymaga skoordynowanej współpracy z instytucjami szczebla centralnego i władzami samorządowymi.

\section{Literatura}

\section{References}

Acs, Z.J., Preston, L. (1997). Small and medium-sized enterprises, technology, and globalization: Introduction to a special issue on small and medium-sized enterprises in the global economy. Small Business Economics, 9(1), 1-6. 
Antonowicz, A., Antonowicz, P., Bieliński, J. (2007). Outsourcing i kooperacja w przemyśle okrętowym. W: P. Antonowicz (red.). Diagnozy, strategie i rozwiq̨zania na rzecz wzrostu zdolności adaptacyjnych pracowników przemysłu okrętowego. Raport finalny z badań i analiz $w$ ramach Partnerstwa Ponadnarodowego SOS Skills Of the Shipyard Employees - kwalifikacje pracowników przemysłu okrętowego. Gdańsk: Instytut Badań nad Gospodarką Rynkową, 67-83.

Antonowicz, A., Antonowicz, P., Bieliński, J., Płoska, R., Valtanen, J. (2007). Przemysł okrętowy w regionie Morza Bałtyckiego. W: P. Antonowicz (red.). Diagnozy, strategie i rozwiqzania na rzecz wzrostu zdolności adaptacyjnych pracowników przemysłu okrętowego. Raport finalny z badań $i$ analiz $w$ ramach Partnerstwa Ponadnarodowego SOS Skills Of the Shipyard Employees - kwalifikacje pracowników przemysłu okrętowego. Gdańsk: Instytut Badań nad Gospodarką Rynkową, 8-39.

Antonowicz, P., Antonowicz, A. (2009). Regionalny potencjał przedsiębiorstw okołostoczniowych województwa pomorskiego. Prace Naukowe Akademii Ekonomicznej w Katowicach. Koniunktura gospodarcza a reakcje podmiotów gospodarujących, 271-284.

Bałtycki Port Nowych Technologii (2016a, 12 lipca). Tereny inwestycyjne. Pozyskano z http:// www.bpnt.eu/pl/oferta/tereny-inwestycyjne

Bałtycki Port Nowych Technologii (2016b, 12 lipca). Otoczenie biznesowe. Pozyskano z http:// www.bpnt.eu/pl/otoczenie-bizensowe

Bałtycki Port Nowych Technologii (2016c, 12 lipca). Biurowiec „Akwarium”. Pozyskano z http:// www.bpnt.eu/pl/oferta/budynek-akwarium

Błuś, M. (2016, 10 lipca). Przyszłość polskich stoczni. Pomorski Przegląd Gospodarczy. Pozyskano z http://ppg.ibngr.pl/pomorski-przeglad-gospodarczy/przyszlosc-polskich-stoczni

Borowiecki, R. (2010). Permanentna restrukturyzacja jako czynnik rozwoju i sukcesu przedsiębiorstw w dobie globalizacji rynku. Zeszyty Naukowe Uniwersytetu Ekonomicznego w Krakowie, 835, 24-28.

Brodzicki, T., Zaucha, J. (2013). Study on Blue Growth, Maritime Policy and EU Strategy for the Baltic Sea Region. Sopot: Instytut Rozwoju. Pozyskano z http://www.instytut-rozwoju.org/ WP/IR_WP2013_04.pdf

Bruce, G., Garrard, I. (2013). The Business of Shipbuilding. Oxford: Informa Law from Routledge.

Christopherson, S., Michie, J., Tyler, P. (2010). Regional resilience: theoretical and empirical perspectives. Cambridge Journal of Regions, Economy and Society, 3(1), 3-10.

Churski, P. (2011). Zmienność rozkładu przestrzennego obszarów wzrostu i obszarów stagnacji gospodarczej w Polsce - uwarunkowania i konsekwencje. Geography, 11(2), 357-369.

Czuczman, J. (2015). Nowoczesny i konkurencyjny polski przemysł stoczniowy na światowym rynku statków. W: A. Chilmon, K. Wyszkowski, Ł. Kolano, M. Gaczkowska, A. Lewandowska, J. Mazurek (red.). Bałtyk dla wszystkich. Warszawa: Global Compact Poland, 136-139.

Duguay, C.R., Landry, S., Pasin, F. (1997). From mass production to flexible/agile production. International Journal of Operations \& Production Management, 17(12), 1183-1195.

Florida, R. (1996). Regional creative destruction: production organization, globalization, and the economic transformation of the Midwest. Economic Geography, 72(3), 314-334.

Karpiński, A., Paradysz, S., Soroka, P., Żółtkowski, W. (2013). Jak powstawały i jak upadały zakłady przemysłowe w Polsce. Warszawa: Muza SA.

Martin, R. (2012). Regional economic resilience, hysteresis and recessionary shocks. Journal of Economic Geography, 12(1), 1-32.

Mitchell, M.L., Mulherin, J.H. (1996). The impact of industry shocks on takeover and restructuring activity. Journal of Financial Economics, 41(2), 193-229.

Najwyższa Izba Kontroli (2011). Informacja o wynikach kontroli zabezpieczenia interesu publicznego w związku z realizacja ustawy kompensacyjnej wobec Stoczni Gdynia SA oraz Stoczni Szczecińskiej Nowa Sp. z o.o. Warszawa: NIK. 
Paradysz, S. (2015). Industrializacja, deindustrializacja i początek reindustrializacji Polski. Wiadomości Statystyczne, 6, 54-65.

Pomorski Park Naukowo-Techniczny (2016a, 13 lipca). Nabór do Parku Konstruktorów. Pozyskano z http://ppnt.pl/pl/oferta/nabor-do-parku-konstruktorow-2

Pomorski Park Naukowo-Techniczny (2016b, 13 lipca). Specjalistyczna infrastruktura. Pozyskano z http://ppnt.pl/pl/konstruktorow/specjalistyczna-infrastruktura

Porter, M.E. (2001). Porter o konkurencji. Warszawa: Polskie Wydawnictwo Ekonomiczne.

Rachwał, T. (2011). Industrial restructuring in Poland and other European Union states in the era of economic globalization. Procedia - Social and Behavioral Sciences, 19, 1-10.

Schumpeter, J.A. (1960). Teoria rozwoju gospodarczego. Warszawa: Państwowe Wydawnictwo Naukowe.

Scott, A.J. (1988). Flexible production systems and regional development: the rise of new industrial spaces in North America and Western Europe. International Journal of Urban and Regional Research, 12(2), 171-186.

Simmie, J., Martin, R. (2010). The economic resilience of regions: towards an evolutionary approach. Cambridge Journal of Regions, Economy and Society, 3(1), 27-43.

Stabryła, A. (2011). Zarzq̨dzanie strategiczne $w$ teorii i praktyce firmy. Warszawa: Wydawnictwo Naukowe PWN.

Stocznia Gdynia SA (2016, 13 lipca). Historia. Pozyskano z http://www.stocznia.gdynia.pl/historia.php

Storper, M. (1989). The geographical foundations and social regulation of flexible production complexes. W: J. Woloch, M. Dear (red.). The power of geography: how territory shapes social life. Oxford: Routledge, 21-40. Pozyskano z http://ci.nii.ac.jp/naid/10003549313/

Stryjakiewicz, T. (1999). Adaptacja przestrzenna przemysłu w Polsce w warunkach transformacji. Poznań: Wydawnictwo Naukowe Uniwersytetu Adama Mickiewicza.

Umiński, S., Wojnicka-Sycz, E., Brodzicki, T., Gawlikowska-Hueckel, K., Kwiatkowski, J. (2015). Analiza branż o największym potencjale eksportowym $w$ województwie pomorskim i badanie potrzeb w zakresie usług wsparcia eksportu przedsiębiorstw ze szczególnym uwzględnieniem branż elektryczno-elektronicznej/ICT, offshore/morskiej oraz farmaceutyczno-medyczno-kosmetycznej wraz z opracowaniem dotyczącym możliwości i sposobów podejmowania działań eksportowych na wybranych rynkach. Gdańsk-Sopot: Instytut Rozwoju. Pozyskano z http:// www.innobaltica.eu/sites/default/files/raport_hz_pom_v.2.pdf

Wach, K. (2015). Przedsiębiorczość jako czynnik rozwoju społeczno-gospodarczego: przegląd literatury. Przedsiębiorczość-Edukacja, 11, 24-36.

Tadeusz Palmowski, prof. dr hab., Uniwersytet Gdański, Instytut Geografii, Katedra Geografii Rozwoju Regionalnego, profesor nauk o Ziemi (specjalność geografia społeczno-ekonomiczna), kierownik Katedry Geografii Rozwoju Regionalnego Uniwersytetu Gdańskiego. Jego zainteresowania badawcze dotyczą gospodarki morskiej, Europy Bałtyckiej, Obwodu Kaliningradzkiego, morskiej współpracy transgranicznej, zagospodarowania przestrzennego obszarów morskich i nadmorskich.

Tadeusz Palmowski, prof. dr hab. The University of Gdańsk, Institute of Geography, Regional Development Geography Department, professor in Earth Science (specialising in social and economic geography), Head of the Department of Regional Development Geography of Gdańsk University. His research focuses on maritime economy, Baltic Europe, Kaliningrad Oblast, maritime cross-border cooperation, spatial management in marine and coastal regions.

Maciej Tarkowski, dr, Uniwersytet Gdański, Wydział Oceanografii i Geografii, Instytut Geografii, Katedra Geografii Rozwoju Regionalnego. Doktor nauk o Ziemi w zakresie geografii. Nauczyciel akademicki w Instytucie Geografii Uniwersytetu Gdańskiego. Zainteresowania badawcze dotyczą geografii ekonomicznej, ze szczególnym uwzględnieniem problematyki lokalizacji działalności gospodarczej, rozwoju lokalnego 
i regionalnego, geografii pracy i ekonomiki miast, w szczególności roli korzyści aglomeracji w procesie polaryzacji rozwoju.

Maciej Tarkowski, Ph.D., University of Gdańsk, Faculty of Oceanography and Geography, Institute of Geography, Department of Regional Development Geography. He holds a Ph.D. in Earth science in the field of geography. He is an academic teacher in the Institute of Geography at the University of Gdańsk. His research interests focus on: economic geography, especially on the issues of economic activity location; local and regional development, labour geography and urban economics and in particular the role of profits of agglomeration in the process of development polarization.

\section{Adres/address:}

Uniwersytet Gdański

Wydział Oceanografii i Geografii

Instytut Geografii

Katedra Geografii Rozwoju Regionalnego

ul. Bażyńskiego 4, 80-309 Gdańsk, Polska

e-mail: tadeusz.palmowski@ug.edu.pl (T. Palmowski)

e-mail: maciej.tarkowski@ug.edu.pl (M. Tarkowski) 